research). Урологія. 2021. т. 25. № 1. Р. 71-80. doi: 10.26641/23075279.25.1.2021.231404

2. Yekhalov V.V., Kravets O.V., Krishtafor D. A. Psychological Features of the Modern Intern. The world of science and innovation. Abstracts of the 6th International scientific and practical conference. Cognum Publishing House. London, United Kingdom. 2021. P. 304-311.

3. Дворник М. С. Прокрастинація в конструюванні особистісного майбутнього: монографія. Кропивницький : Імекс-ЛТД. 2018. 120 с.

4. Yekhalov V. V., Gorbuntsov V.V. Psychological features of a modern intern dinamic observation. Bioenergetics in Medicine and Biology. 2021. V. 1(6). P. 1-20. doi: 10.26886/2523-6938.1(6)2021.1.

5. Колесникова В.И., Денисенко Ю. С. Теоретический анализ феномена прокрастинации в парадигме глубинной психологии. Психология и педагогика в Крыму: пути развития. 2020. № 2. С. 155-172.

DOI https://doi.org/10.30525/978-9934-26-182-4-25

\title{
АНОСМІЯ ТА ПАРОСМІЯ У ПОСТКОВІДНИЙ ПЕРІОД. ОСОБЛИВОСТІ ЗМІН НЮХУ
}

\author{
Коломійченко Ю. В.
}

студентка 3 курсу медичного факультету

Одеський національний медичний університет

\author{
Кузьменко I. A. \\ кандидат медичних наук, \\ дочент кафедри Загальної та клінічної патологічної фізіології \\ імені В. В. Підвисочького \\ Одеський національний медичний університет \\ м. Одеса, Україна
}

Аносмія та паросмія - найбільш розповсюджені симптоми прояву класичного SARS-CoV-2 та інших штамів на ранніх етапах інфікування, але не $\epsilon$ маркерними симптомами, оскільки ці порушення нюху можуть виникати при синуситах, респіраторних інфекціях, черепно-мозкових травмах i т.д.. Вони тимчасові та можуть бути короткочасними або довготривалими. Аносмія дуже часто супроводжується адгезією. В постковідний період для оцінки рівня пошкодження нюху, 
використовують суб'єктивний та об'єктивний метод ольфактометрії. Довготривале порушення нюху не рідко спричинює виникнення депресії, схуднення та інших проблем зі здоров'ям.

Коронавіруси - це позитивні одноланцюгові великі оболонкові РНКвмісні віруси, які вперше були описані в 1966 році Tyrell и Вуnое як збудники гострих респіраторних інфекцій. Існує 4 субродини коронавірусів: альфа-, бета-, гамма- и дельта-коронавіруси. SARS-CoV-2 $\epsilon$ бета-коронавірусом [1] .

Пацієнти, які страждають на паросмію можуть відчувати такі запахи, як: паління, горілого, смаженого, оцту, зіпсованого м'яса та яєць, амоніаку, бензину, асфальту, стічних вод, плісняви та інші. Серед 5 найбільш частих типів їжі, що могли ініціювати паросмію - це: курка та інше м'ясо, ріпчаста цибуля, яйця, часник та рис [2].

Існує декілька припущень щодо патогенезу порушення нюху у пацієнтів в постковідний період, загалом вони базуються на механізмах проникнення SARS-CoV-2 в організм людини, особливостях будови та функцій нюхового епітелію.

1. SARS-CoV-2 інфікує клітини слизової оболонки носової порожнини через взаємодію зі спайковим протеїном та ACE2 протеїном, розташованим на клітинах-мішенях. Цей процес супроводжується розщепленням S-білка ферментами поверхневих клітин такими як: TMPRSS2 та іншими. Носовий епітелій складається з респіраторного епітелію та нюхового епітелію. В структуру нюхового епітелію входять базальні та війчасті клітини, секреторні та мікроворсинчасті клітини, нюхові сенсорні нейрони. Нюхові сенсорні клітини підтримуються підтримуючими клітинами, які приймають участь у структурній підтримці сенсорних нейронів, фагоцитозі та/або детоксикації потенційно пошкоджуючих агентів, та головним чином у водно-сольовому балансі. Мікроворсинчасті клітини та Боуменові залози грають важливу роль у гомеостазі нюхового епітелію. Нюховий епітелій містить кулясті базальні клітини, які приймають участь у регенерації нюхових сенсорних нейронів під час нормального епітеліального оновлення, та горизонтальні базальні клітини, які діють як резервуар стовбурових клітин, які активуються під час пошкодження епітелію. Підтримуючі та стовбурові нюхові клітини, але не зрілі нюхові сенсорні нейрони, $є$ потенційно прямою мішенню SARS-CoV-2 в людському нюховому епітелії [3]. Метою вірусу $\epsilon$ ненейронні клітини, які експресують АCE2 рецептори такі як: підтримуючі та мікроворсинчасті клітини, боуменові залози, горизонтальні базальні клітини та перицити нюхових бульб [4]. 
2. Механічна блокада запаленням, яке виникає навколо нюхової щілини, що запобігає входу одорантів через нюхові рецептори [5].

Рівень експресії ACE2 протеїнів у людей похилого віку в рази вищий, що пояснює вищу чутливість цієї категорії людей до інфікування [6].

Між тим, серед 60 опитаних, 85\% пацієнтів хворіли Covid-19. У 55\% захворювання було лабораторно підтверджено. Пацієнти були різної вікової категорії: 61,7\% - від 35 до 60 років, 33,3\% - від 18 до 35 років, $5 \%$ - 60+ років. У 71,9\% пацієнтів виникали проблеми з нюхом під час хвороби. Порушення нюху були різними: 55,8\% пацієнтів страждали на зникнення нюху, у 30,2\% - спочатку нюх зникав, потім відновлювався зміненим, у 14\% - нюх змінювався. Крім того, тривалість порушення нюху було різноманітним: у $37,2 \%$ - нюх нормалізувався до 7 днів, у 23,3\% - від 1-го до 3-х тижнів, у 23,3\% - від 3-х до 6-ти тижнів, у 11,6\%більше 1,5 місяця потрібно було для відновлення, у 4,6\% - 6+ місяців. При зміненні нюху найчастіше пацієнтів турбували запахи ацетону та зіпсованих яєць, часто - запах гниття та диму, зіпсованого м'яса та горілого, i, рідше всього - відчуття оцту та бензину.

Отже, аносмія та паросмія притаманні класичному штаму SARS-CoV2 та таким як: альфа-коронавірус, кластер 5 та лямбда-коронавірус. Більшість мутацій виникають всередині спайкового протеїна, що зумовлюе появу більш інвазивного вірусу. N501Y мутація посилює зв'язування між SARS-CoV-2 S-білком та людським ACE2 рецептором [7]. Оскільки альфа штам має спільну мутацію N501Y з бета- та гаммаваріантом, ми можемо припустити, що аносмія та паросмія можуть виникати і при захворінні даними штамами, оскільки чим вища здатність зв'язування спайкового протеїна з АСЕ2 рецептором клітини-хазяїна, тим вища контагіозність.

Швидкість функціонального відновлення залежить від індивідуальних особливостей, таких як : вік пацієнта, рівень пошкодження клітин, тяжкість перебігу хвороби, активність цитокінів, наявність або відсутність атрофічних змін слизової оболонки носової порожнини, наявність супроводжуючих захворювань (наприклад: концентрація АCE2 може підвищуватись після ішемічного інсульту [8], наявність/відсутність уживаних білків тваринного походження в раціоні харчування, які впливають на швидкість регенерації клітин та рівень синтезу білків. Рівень та якість відчуття запахів залежить від швидкості функціонального відновлення клітин та деяких особливостей нейрогуморальної регуляції. 


\section{Література:}

1. Абатуров А.Е., Агафонова Е.А., Кривуша Е.Л., Никулина А.А. Патогенез COVID-19. Здоров'я дитини=Zdorov'e Rebenka, T. 15 (№ 2). C. 133-144. DOI: 10.22141/2224-0551.15.2.2020.200598

2. Parosmia After COVID-19: What to Know. https://www.healthline.com/ health/parosmia-after-covid\#overview

3. David H. Brann, Tatsuya Tsukahara, Caleb Weinreb. Nonneuronal expression of SARS-CoV-2 entry genes in the olfactory system suggests mechanisms underlying COVID-19-associated anosmia. SCIENCE ADVANCES $31 \mathrm{Jul} 2020 \mathrm{Vol}$ 6, Issue 31 DOI: 10.1126/sciadv.abc5801

4. Albert Y Han, Laith Mukdad, Jennifer L Long, Ivan A Lopez. Chemical Senses, Volume 45, Issue 6, July 2020, Pages 423-428, https://doi.org/10.1093/chemse/bjaa040

5. Saniasiaya J, Narayanan PParosmia post COVID-19: an unpleasant manifestation of long COVID syndrome. Postgraduate Medical Journal Published Online First: 31 March 2021. doi: 10.1136/postgradmedj-2021139855

6. José Claudio da Silva, Valtuir Barbosa Félix, Sura Amélia Barbosa Felix Leão, Euclides Maurício Trindade-Filho, Fulvio Alexandre Scorza. New Brazilian variant of the SARS-CoV-2 (P1/Gamma) of COVID-19 in Alagoas state. The Brazilian Journal of Infectious Diseases. Volume 25, Issue 3, May-June 2021, 101588. https://doi.org/10.1016/j.bjid.2021.101588

7. SARS-CoV-2 Variants: Evading the Immune System. https://bpsbioscience.com/sars-cov-2-variants

8. Полина Олеговна Шатунова, Анатолий Сергеевич Быков, Оксана Анатольевна Свитич, Виталий Васильевич Зверев. Ангиотензинпревращающий фермент 2. Подходы к патогенетической терапии COVID-19. Журнал микробиологии, эпидемиологии и иммунобиологии Том 97, № 4 (2020) https://doi.org/10.36233/0372-9311-2020-97-4-6 